\title{
ANALISIS PEMBELAJARAN TARI TRADISIONAL DALAM PENDIDIKAN KARAKTER SISWA SEKOLAH DASAR
}

\author{
Al Fadhil Ramdani* \\ Arina Restian \\ Isqi Agustin Cahyaningtiyas
Pendidikan Guru Sekolah Dasar, Fakultas Keguruan dan Ilmu Pendidikan, Universitas Muhammadiyah Malang Jalan Raya Tlogomas 246 Malang, Indonesia \\ *e-mail: alfadilramdani@yahoo.co.id
}

Artikel diterima: 20 Mei 2020; disetujui: 30 November 2020

\begin{abstract}
This study aims to describe the form of dance learning activities for elementary school students at the Pelangi Pujon Dance Studio, classify the character forms of elementary school students at the Pelangi Pujon Dance Studio, and describe the impact of dance learning on student characteristics. This research uses qualitative research with descriptive methods. The results showed that the activities of elementary school students at the Pelangi Pujon Dance Studio were not only focused on dancing practice, but interspersed with the cultivation of character education during learning. The forms of character that are implanted include cooperation, empathy, independence, courtesy and help. The impact of learning this dance is the student's habit of applying positive characters in everyday life.
\end{abstract}

Keywords: traditional dance lessons; character education; dance studio

\begin{abstract}
Abstrak: Penelitian ini bertujuan mendeskripsikan bentuk kegiatan pembelajaran tari bagi siswa sekolah dasar di Sanggar Tari Pelangi Pujon, mengklasifikasikan bentuk karakter siswa sekolah dasar di Sanggar Tari Pelangi Pujon, dan mendeskripsikan dampak pembelajaran tari terhadap karakteristik siswa. Penelitian ini menggunakan jenis penelitian kualitatif dengan metode deskriptif. Hasil penelitian menunjukkan kegiatan siswa sekolah dasar di Sanggar Tari Pelangi Pujon tidak hanya terfokus latihan menari, tetapi diselingi penanaman pendidikan karakter selama pembelajaran. Bentuk-bentuk karakter yang ditanamkan antara lain kerjasama, empati, kemandirian, sopan santun dan tolong menolong. Dampak dari pembelajaran tari ini adalah kebiasaan siswa dalam menerapkan karakter positif dalam kehidupan sehari-hari.
\end{abstract}

Kata kunci: pembelajaran tari tradisional; pendidikan karakter; sanggar tari

\section{PENDAHULUAN}

Pembelajaran menjadi salah satu wadah dalam menampung berbagai macam proses kegiatan siswa untuk mencapai hasil yang diinginkan. Pembelajaran seni dan budaya adalah salah satu bentuk pendukung dalam mencapai tujuan pendidikan (Kusumastuti, 2014). Tujuan utama pembelajaran seni dan budaya adalah untuk memberikan pemahaman tentang kebermaknaan suatu 
karya yang dapat membawa dampak dalam kepribadian seseorang. Seni dalam rangkaian dunia pendidikan dimanfaatkan sebagai supporter pendidikan, terutama dalam proses meningkatkan kepekaan rasa sosial, cinta budaya dan bangsa, sadar rasa jati diri, serta cerdas dalam menalar untuk kepentingan bangsa (Iriani, 2012). Hal ini terbukti bahwa peran pembelajaran seni dan budaya dalam dunia pendidikan sangatlah penting.

Salah satu pembelajaran yang termasuk kategori dalam bidang seni dan budaya adalah tari tradisional. Seni tari adalah bentuk pengungkapan ekspresi diri dalam berkomunikasi dengan harapan dapat mempengaruhi sikap anak, dari yang awalnya natural menjadi sikap yang dapat memahami kondisi sosial budaya lingkungan sekitarnya (Sustiawati, Suryatini, dan Mayun Artati 2018). Saat ini kegiatan tari tidak hanya terdapat pada kegiatan ekstrakulikuler sekolah saja tetapi dapat dijumpai diberbagai sanggar yang ada di masyarakat. Selain pengungkapan ekspresi diri, seni tari juga dapat menjadi media dalam membentuk karakter.

Kegiatan pembelajaran tari pada mata pelajaran seni dan budaya di sekolah dasar pada prinsipnya bertujuan untuk memberikan kemudahan dan menampung berbagai macam peluang siswa dalam mengembangkan minat dan bakat yang mereka miliki bukan untuk mengeksploitasi dan mendoktrin mereka untuk harus bisa menari. Pada dasarnya setiap individu siswa memiliki keunggulan tersendiri yang tidak bisa disamakan (Arisyanto. dkk., 2018). Oleh karena itu, pendidik dituntut tidak hanya bisa memiliki kompetensi kognitif dalam mengajar namun juga harus memiliki kemampuan untuk memahami kepribadian siswa didik.

Bagi pendidik untuk memahami kepribadian siswa hendaknya dapat mengolah kondisi pembelajaran untuk selalu menyisipkan berbagai pendidikan karakter yang sesuai dengan tujuan pembelajaran seni dan budaya. Pendidikan karakter merupakan sebuah model pembelajaran yang memfokuskan siswa dalam menyesuaikan kepribadian masyarakat bangsa Indonesia. Bentuk pendidikan karakter secara umum diistilahkan sebagai sebuah kepompong bagi siswa dalam menanggapi berbagai pendatang budaya dari kultur yang berbeda. Pendidikan karakter dapat berarti sebagai pendidikan budi pekerti, pendidikan nilai, pendidikan moral dan pendidikan sifat, dengan tujuan mengembangkan siswa didik dalam memberikan keputusan baik atau buruknya sesuatu, mengolah kebaikan, mewujudkan serta menebarkan kebaikan dalam kehidupan sehari-hari (Putri, 2019) .

Pentingnya pendidikan karakter karena menjadi pondasi utama dalam mendidik siswa untuk meningkatkan kualitas sumber daya manusia yang berkarakter. Pertama, langkah terbaik untuk menjamin siswa memiliki sifat yang baik dalam hidupnya. Kedua, langkah terbaik untuk meningkatkan prestasi ilmiah (ilmu pengetahuan). Ketiga, siswa tidak menempatkan kepribadian disatu tempat. Keempat, mempersiapkan siswa untuk menghadapi perbedaan keberagaman masyarakat, dengan belajar menghormati orang lain. Kelima, bercermin dari permasalahan yang 
meliputi moral-sosial, seperti perilaku tidak jujur, pelanggaran kegiatan, intimidasi, ketidaksopanan, etos kerja yang rendah dan seksualitas. Dari kelima poin ini dapat disimpulkan bahwa pendidikan karakter tidak hanya mengajarkan sesuatu yang boleh atau yang tidak boleh saja, namun pendidikan karakter berguna untuk menanamkan kebiasaan (habituation) tentang sesuatu yang baik, sehingga yang terjadi adalah peserta didik dapat memahami, dapat merasakan serta mau melakukan sesuatu yang baik (Suryaman \& Karyono, 2018).

Berkaitan dengan pentingnya pendidikan karakter, terdapat beberapa nilai yang diterapkan oleh sekolah-sekolah di Indonesia dengan tujuan menanamkan budi pekerti luhur dan ciri khas bangsa Indonesia. Menurut Permendiknas No.2 Tahun 2010, nilai- nilai dalam pendidikan karakter yaitu: toleransi, religius, jujur, toleransi, disiplin, kreatif, kerja keras, demokratis, rasa ingin tahu, cinta tanah air, semangat kebangsaan, menghargai prestasi, bersahabat atau komunikatif, gemar membaca, cinta damai, peduli sosial, peduli lingkungan dan tanggung jawab (Putri, 2013) . Nilainilai tersebut dapat diringkas secara garis besar dan sudah mencangkup nilai yang lainya, nilai tersebut diantaranya, religius, nasionalisme, gotong royong, integritas dan mandiri.

Penelitian ini berdasarkan dengan teori Lickona yang menekankan bahwa tiga komponen karakter yang penting yaitu moral knowing atau pengetahuan yang meliputi moral, moral feeling atau perasaan tentang moral, dan moral action atau tindakan moral. Ketiga poin tersebut diperlukan agar anak mampu memahami, merasakan dan mengerjakan sekaligus nilai-nilai kebijakan yang berlaku (Arisyanto, dkk., 2018). Dari teori tersebut dapat disimpulkan bahwa dalam pendidikan karakter ada tiga aspek yang harus dipenuhi antara lain aspek pengetahuan (cognitive), perasaan (feeling) dan tindakan (action) tanpa ketiga aspek tersebut, maka yang terjadi pendidikan karakter tidak berjalan dengan efektif.

Penelitian tentang tari sebagai sarana pendidikan karakter juga telah banyak dilakukan oleh peneliti terdahulu. Penelitian Hartini (2016) tentang tari semut menunjukkan tari dapat digunakan sebagai media pendidikan karakter, yaitu melalui tari siswa akan belajar untuk saling berkejasama untuk menghasilkan tarian yang padu berbasis kearifal lokal daerah. Pada penelitian lainnya juga menunjukkan bahwa melalui seni tari siswa dapat belajar mengenali hubungan antar anggota tubuhnya, kerjasama, peduli, santun, disipin, dan mencintai budaya melalui proses pembelajarannya (Setiawan, 2019). Kedua hasil penelitian ini menunjukkan bahwa pendidikan karakter yang berorientasi pada pendekatan moral reasoning melalui pembelajaran pendidikan seni tari tercermin dalam toleransi, solidaritas, dan kebersamaan. Berdasarkan hal tersebut, pada penelitian ini akan dianalisis pembelajaran tari di sekolah dasar dengan fokus penelitian untuk (1) mendeskripsikan bentuk kegiatan pembelajaran tari tradisional di Sanggar Tari Pelangi Pujon; (2) mengklasifikasikan bentuk karakter siswa SD di Sanggar Tari Pelangi Pujon; dan (3) 
mendeskripsikan dampak hasil pembelajaran tari terhadap karakteristik siswa SD di Sanggar Tari Pelangi Pujon.

\section{METODE}

Penelitian ini menggunakan penelitian dengan pendekatan deskriptif. Sumber data dalam penelitian ini adalah hasil observasi, hasil wawancara dan hasil angket tertutup yang dikembangkan oleh penulis. Pelaksanaan penelitian ini dilakukan pada bulan Maret 2020 yang bertempat di Sanggar Tari Pelangi Pujon, Kota Malang. Pengumpulan data dalam penelitian ini dengan cara observasi yang dilakukan dengan mengamati tingkah laku siswa pada saat pembelajaran tari di Sanggar Tari Pelangi secara langsung. Subjek wawancara atau narasumber dalam penelitian ini berinisial SP. SP memegang peranan sebagai pendiri Sanggar Tari Pelangi Pujon. Alasan utama memilih subjek wawancara SP dalam penelitian ini adalah untuk mendapatkan data yang informatif dan aktual.

Wawancara dilakukan kepada pendiri Sanggar Tari Pelangi dan membagikan angket tertutup kepada siswa Sanggar Tari Pelangi. Wawancara kepada pemilik sanggar tari dilakukan dengan mengajukan beberapa pertannyaan seputar perkembangan karakter siswa di Sanggar Tari Pelangi. Hal ini dilakukan untuk menambah sudut pandang penilaian terhadap perkembangan siswa di Sanggar Tari Pelangi. Angket tertutup sebagai media pengumpulan data pada penelitian ini, dibagikan kepada lima belas siswa di sanggar, yag terdiri dari tiga belas siswa SD dan dua siswa TK. Kisi-kisi angket yang digunakan dalam penelitian ini ditunjukkan pada Tabel 1.

Tabel 1. Kisi-Kisi Angket untuk Siswa

\begin{tabular}{ll}
\hline No. & \multicolumn{1}{c}{ Kisi-Kisi Angket } \\
\hline 1. & Pertanyaan yang membahas kejujuran siswa \\
2. & Pertanyaan yang berisi keterbukaan siswa dalam bicara \\
3. & Pertanyaan seputar kemampuan siswa dalam berinteraksi dengan lingkungan sekitar \\
4. & Pertanyaan terkait dengan kedisiplinan yang dilakukan siswa \\
5. & Pertanyaan terkait dengan kemampuan siswa dalam mengevaluasi ekspresi diri \\
6. & Pertanyaan tentang sikap ketaatan siswa \\
7. & Pertanyaan seputar kemampuan siswa mengapresiasi diri sendiri \\
8. & Pertanyaan tentang kemampuan berbicara didepan umum \\
9. & Pertanyaan yang membahas kemampuan siswa dalam mendengarkan lawan bicara \\
10. & Pertanyaan tentang keterampilan siswa dalam berbagi kebaikan \\
11. & Pertanyaan seputar keterampilan siswa dalam berbagi kebaikan \\
12. & Pertanyaan terkait keberanian siswa dalam bertanya \\
13. & Pertanyaan mengenai aspek tanggung jawab \\
14. & Pertanyaan yang membahas kemampuan kegigihan siswa \\
15. & Pertanyaan seputar kemampuan dalam menerima kritik dan saran \\
\hline
\end{tabular}




\section{HASIL DAN PEMBAHASAN}

\section{Kegiatan Pembelajaran Tari di Sanggar Tari Pelangi Pujon}

Kegiatan pembelajaran membawa pengaruh terhadap pola pikir siswa yang nantinya akan berdampak pada sikap dan pemikiran terhadap siswa. Terkait dengan pembelajaran tari, hasil penelitian menunjukkan bahwa bentuk pembelajaran tari tradisional di Sanggar Tari Pelangi Pujon membawa dampak positif bagi karakter siswa sebagaimana disajikan pada kutipan hasil wawancara, "dalam kegiatan tari kita bagi beberapa divisi yang nantinya siswa juga akan mempelajari daalam kehidupan nyata, seperti manajemen dan lain sebagainya" (W/SP).

Lebih lanjut diperoleh data bahwa kegiatan yang dilakukan tidak hanya belajar tari saja, akan tetapi pembelajaran juga diselingi dengan pembelajaran pengorganisasian. Di Sanggar Tari Pelangi Pujon terdapat beberapa divisi yang sudah terbagi dengan tujuan terbaginya divisi tersebut untuk mengedukasi siswa dalam hal pengorganisasian. Pengorganisasian tersebut meliputi beberapa divisi, antara lain divisi sekretaris dan bendahara, divisi manajemen kegiatan, divisi make up dan kostum. Pengorganisasian inilah yang akan membentuk perilaku atau sikap sesorang dalam berinteraksi kepada orang di sekitar. Sejalan dengan pernyataan tersebut terbukti bahwa kegiatan organisasi dapat digunakan sebagai sarana penanaman atau pelaksanaan pendidikan karakter siswa (Fibrianto \& Yuniar, 2020). Hasil pendidikan karakter ini juga akan berdampak menjadi kebiasaan siswa dalam kehidupan sehari-hari (Rahma Pratiwi, 2018).

Kegiatan tari juga diselingi dengan pembelajaran pendidikan karakter dalam upaya siswa dapat menjadi pribadi dan insan yang memiliki karakter yang baik. Hal itu dibuktikan dengan kutipan hasil wawancara, "selain menari, kita isi juga dengan pendidikan karakter, penari itukan seharusnya kita tidak boleh malu, tidak boleh demam panggung, percaya diri, tanggung jawab, kerja sama yang baik dengan tim dan harus tau untuk apa kita nari” (W/SP). Dari data tersebut diketahui bahwa diterapkan beberapa poin karakter untuk membentuk siswa supaya berkarakter yang baik. Tanggung jawab dan rasa percaya diri terhadap dirinya sendiri menjadi kunci utama dalam menari dan harus dimiliki seorang penari. Penerapan pendidikan karakter bertujuan untuk membentuk karakter siswa yang baik dan beretika (Fajarini, 2014). Proses ini penerapan ini terjadi dalam berbagai aktivitas pembelajaran yang secara tidak langsung akan terinternalisasi dalam diri siswa (Wuryandani dkk., 2014).

\section{Bentuk Karakter Siswa SD dalam Pemeblajaran Tari di Sanggar Tari Pelangi Pujon}

Sesuai fokus penelitian kedua yaitu mengklasifikasikan bentuk-bentuk karakter dari hasil pembelajaran tari diperoleh data sebagai berikut. Lima belas siswa yang mengisi angket menunjukkan jawaban yang berbeda. Dari angket yang dibagikan diperoleh sebaran hasil yang ditunjukkan Tabel 2. 
Tabel 2. Sebaran Hasil Pengisian Angket oleh Siswa

\begin{tabular}{lclcc}
\hline No & N & Kriteria & Poin Pengisian & Hasil Pengisian \\
\hline 1 & 15 & STS (sangat tidak setuju) & 1 & 0 \\
2 & & TS (tidak setuju) & 2 & 2 \\
3 & & S (setuju) & 3 & 91 \\
4 & & SS (sangat setuju) & 4 & 137 \\
\hline
\end{tabular}

Hasil dari pengisian angket tertutup yang dibagikan dan sudah diisi oleh siswa Sanggar Tari Pelangi menunjukkan bahwa bentuk karakter yang dimiliki siswa SD adalah (1) adannya rasa tanggung jawab yang tinggi terhadap dirinya untuk melaksanakan kewajibannya sebagai siswa, (2) peduli sosial dengan membantu temannya yang kurang paham dalam mengisi angket, siswa peka untuk membantu temannya yang kesulitan tersebut, (3) kemandirian siswa Sanggar Tari Pelangi juga tercermin dalam kegiatan proses belajarnya yang dibuktikan dengan adanya siswa yang mengisi angket tertutup dengan memperhatikan petunjuk yang sudah tertera, (4) kekreatifan siswa dalam membuat koreografi tarian menjadi bukti bahwa siswa mengimplementasikan nilai pendidikan karakter dalam proses belajarnya. Keempat bentuk karakter siswa di atas termasuk kedalam bagian nilai-nilai karakter. Pada dasarnya setiap individu mememiliki bentuk karakter dasar yang perlu ditanamkan dan dilatih, supaya dapat berkembang dan diimplementasikan dalam kehidupan sehari-hari (Judiani, 2010). Karakter dasar yang banyak dimiliki setiap individu, diantaranya jujur, adil, tanggung jawab, kerja sama dan peduli. Karakter dasar tersebut menjadi pegangan utama dalam penenaman nilai pendidikan karakter lainya (Maunah, 2016).

Selama penelitian juga diperoleh potret siswa dalam menerapkan karakter positif. Siswa menyatakan terbiasa untuk selalu berdiskusi dan mengahargai pendapat temannya saat memilih kostum, saling mengkoreksi dan membenarkan gerakan temannya dengan bimbingan pengajar. Hal ini juga tercermin saat berdiskusi, salah satu dari siswa memberitahu bagian yang kedua temannya belum paham tentang angket yang harus diisi. Satu siswa tersebut dalam kegiatan ini termasuk menerapkan rasa tanggung jawab dan saling tolong menolong serta berempati kepada temannya. Kebiasaan ini selalu diterapkan saat pembelajaran tari dan dalam kehidupan sehari-hari. Gambar 1 menunjukkan potret aktivitas siswa saat berdiskusi dan menerapan karakter tolong menolong dan empati saat pengisian angket.

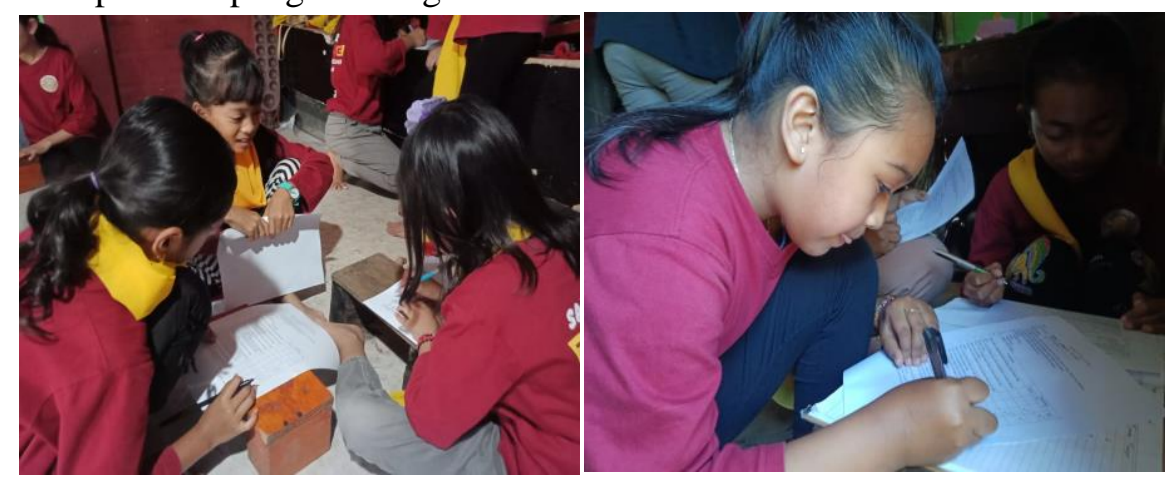

Gambar 1. Interkasi Siswa Saat Berdiskusi 
Selain karakter tersebut, selama penelitian juga nampak kemandirian yang dilakukan siswa tersebut sebagai bentuk intergrasi siswa terhadap pendidikan karakter. Karakter mandiri tersebut secara tidak sadar dilakukan oleh siswa, sebab pendidikan karakter yang diterapkan oleh pembimbing sanggar. Dampak dari penerapan pendidikan karkter tersebut adalah siswa mempunyai karakter yang baik dalam menjalani segala bentuk kegiatan dalam kehidupannya (Desyandri, 2018). Bentuk-bentuk karakter ini termasuk nilai-nilai pendidikan karakter yang tertuang dalam buku pengembangan pendidikan budaya dan karakter bangsa yang disusun oleh kementrian pendidikan dan budaya melalui badan penelitian dan pengembangan pusat kurikulum (Priyatna, 2017). Nilai-nilai pendidikan karakter tersebut adalah (1) religius, (2) jujur, (3) toleransi, (4) disiplin, (5) kerja keras, (6) kreatif, (7) mandiri, (8) demokratis, (9) semangat kebangsaan atau nasionalisme, (10) cinta tanah air, (11) menghargai prestasi, (12) komunikatif, (13) cinta damai, (14) gemar membaca, (15) peduli lingkungan, (16) peduli sosial, (17) tanggung jawab, (18) rasa ingin tahu (Ridwan \& Mas'odi, 2017).

\section{Dampak Pembelajaran Tari Terhadap Karakteristik Siswa di Sanggar Tari Pelangi Pujon}

Dampak dari pembelajaran tari terhadap karakteristik siswa SD di Sanggar Tari Pelangi Pujon adalah perubahan baik yang terdapat pada sikap siswa, serta siswa memiliki potensi karakter yang berciri khas. Hal ini dibuktikan dengan data wawancara, "menggunakan bahasa Jawa yang sopan, budaya salim mulai terbiasa dilakukan ketika datang guru atau pembimbing datang" (W/ $S P)$. Data ini menunjukkan dampak dari pembelajaran tari terhadap sikap siswa yaitu menggunakan bahasa Jawa yang halus dalam berkomunikasi antar siswa dan guru atau pembimbing menjadi kategori tolak ukur tingkat kesopanan siswa terhadap guru atau pembimbing. Mengingat bahasa Jawa halus juga diajarkan kepada siswa dalam proses pembelajaran tari. Perubahan sikap siswa menjadi hasil utama dalam pemebalajaran pendidikan karakter. Sikap yang dulunya kurang baik dan kurang sopan, kini mengalami perubahan setelah mendapatkan edukasi pendidikan karakter pada pembelajran tari.

Salah satu contoh yang diterapkan siswa dalam mempertahankan karakter dirinya yang baik yaitu dengan cara menerapkan budaya cium tangan kepada guru atau pembimbing. Budaya cium tangan adalah budaya mencium tangan kepada orang yang lebih tua dalam konteks tertentu, contohnya kepada guru di sekolah atau kepada orang tua ketika akan bepergian. Budaya cium tangan ini diterapkan di Jawa (Hendriana \& Jacobus, 2017). Tujuan budaya cium tangan diterapkan dan menjadi sebuah kebiasaan adalah untuk menghormati orang yang lebih tua, sehingga akan membentuk karakter anak atau siswa yang mulia (Fatmawati, 2015). Budaya cium tangan juga termasuk dalam kategori nilai pendidikan karakter, yaitu pada nilai saling menghargai dan religious (Muslich, 2018). 


\section{SIMPULAN DAN SARAN}

\section{Simpulan}

Penerapan pendidikan karakter dilakukan selama kegiatan pembelajaran tari di Sanggar Tari Pelangi Pujon. Pendidikan karakter tersebut diterapkan dalam pengorganisasian pembelajaran, penerapan budaya cium tangan/salim, penggunaan bahasa Jawa halus dalam berkomunikasi, rasa toleransi kepada teman atau lingkungan sekitar dan tanggung jawab dirinya sebagai siswa. Bentukbentuk karakter yang ditanamkan antara lain kerjasama, empati, kemandirian, sopan santun dan tolong menolong. Dampak pembelajaran tari terhadap karakter siswa SD di Sanggar Tari Pelangi Pujon yaitu siswa mempunyai karakter yang baik sesuai dengan karakter siswa yang berbudaya dan berbangsa untuk diterapkan dalam kehidupan sehari-hari.

\section{Saran}

Berdasarkan penelitian ini, disarankan untuk menambah model kegiatan pendidikan karakter yang bervariasi dalam pembelajaran tari. Model kegiatan pendidikan karakter yang bervariasi dapat menjadikan siswa lebih banyak mengembangkan kemampuan dan mengelola kondisi dirinya dalam kondisi apapun yang terjadi dihadapannya.

\section{DAFTAR RUJUKAN}

Arisyanto, P., Sundari, R. S., \& Untari, M. F. A. (2018). Pembelajaran Ekstrakurikuler Tari Untuk Penanaman Karakter Bagi Siswa SD Negeri Gayamsari 02 Semarang. Jurnal Pendidikan Dan Kajian Seni, 3(1). Https://Doi.Org/10.30870/Jpks.V3i1.4062

Desyandri, D. (2018). Nilai-Nilai Kearifan Lokal Untuk Menumbuhkembangkan Literasi Budaya Di Sekolah Dasar. Sekolah Dasar: Kajian Teori Dan Praktik Pendidikan, 27(1), 1-9. Https://Doi.Org/10.17977/Um009v27i12018p001

Fajarini, U. (2014). Peranan Kearifan Lokal Dalam Pendidikan Karakter. Sosio Didaktika: Social Science Education Journal, 1(2), 123-130. Https://Doi.Org/10.15408/Sd.V1i2.1225

Fatmawati, D. (2015). Strategi Guru Pendidikan Agama Islam Dalam Membentuk Karakter Siswa Di Smp Negeri 13 Malang Skripsi. 160.

Fibrianto, A. S., \& Yuniar, A. D. (2020). Peran Budaya Organisasi Dalam Pembentukkan Karakter, Etika Dan Moral Siswa SMA Negeri Di Kota Malang. Jurnal Analisa Sosiologi, 9(1). Https://Doi.Org/10.20961/Jas.V9i1.41372

Hartini, H. (2016). Tari Semut Sebagai Media Pengembangan Karakter Bagi Siswa Sekolah Dasar. Premiere Educandum: Jurnal Pendidikan Dasar Dan Pembelajaran, 3(02). Https://Doi.Org/10.25273/Pe.V3i02.277

Hendriana, E. C., \& Jacobus, A. (2017). Implementasi Pendidikan Karakter Di Sekolah Melalui Keteladanan Dan Pembiasaan. JPDI (Jurnal Pendidikan Dasar Indonesia), 1(2), 25. Https://Doi.Org/10.26737/Jpdi.V1i2.262

Iriani, Z. (2012). Peningkatan Mutu Pembelajaran Seni Tari Di Sekolah Dasar. Komposisi: Jurnal Pendidikan Bahasa, Sastra, Dan Seni, 9(2). Https://Doi.Org/10.24036/Komposisi.V9i2.98 
Judiani, S. (2010). Implementasi Pendidikan Karakter Di Sekolah Dasar Melalui Penguatan Pelaksanaan Kurikulum. Jurnal Pendidikan Dan Kebudayaan, 16(9), 280. Https://Doi.Org/10.24832/Jpnk.V16i9.519

Kusumastuti, E. (2014). Penerapan Model Pembelajaran Seni Tari Terpadu Pada Siswa Sekolah Dasar. Mimbar Sekolah Dasar, 1(1). Https://Doi.Org/10.17509/Mimbar-Sd.V1i1.858

Maunah, B. (2016). Implementasi Pendidikan Karakter Dalam Pembentukan Kepribadian Holistik Siswa. Jurnal Pendidikan Karakter, 1. Https://Doi.Org/10.21831/Jpk.V0i1.8615

Muslich, A. (2018). Nilai-Nilai Filosofis Masyarakat Jawa Dalam Konteks Pendidikan Karakter Di Era Milenial. Al-Asasiyya: Journal Of Basic Education, 2(2). Https://Doi.Org/10.24269/Ajbe.V2i2.1119

Priyatna, M. (2017). Pendidikan Karakter Berbasis Kearifan Lokal. Edukasi Islami: Jurnal Pendidikan Islam, 5(10). Https://Doi.Org/10.30868/Ei.V5i10.6

Putri, D. I. (2019). Penguatan Program Pendidikan Karakter (Ppk) Melalui Kegiatan Ekstrakulikuler Seni Tari Di SD. Pendas: Jurnal Ilmiah Pendidikan Dasar, 4(1), 125. Https://Doi.Org/10.23969/Jp.V4i1.1301

Putri, N. A. (2013). Penanaman Nilai-Nilai Pendidikan Karakter Melalui Mata Pelajaran Sosiologi. Komunitas: International Journal Of Indonesian Society And Culture, 3(2). Https://Doi.Org/10.15294/Komunitas.V3i2.2317

Rahma Pratiwi, E. Y. (2018). Kualitas Media Card Dance Untuk Pembelajaran Seni Tari Di Lembaga Pendidikan. Jurnal Bidang Pendidikan Dasar, 2(2), 1-10. Https://Doi.Org/10.21067/Jbpd.V2i2.2534

Ridwan, M., \& Mas'odi, M. (2017). Tradisi Nyanyian Anak Terhadap Pembentukan Karakter Anak Usia Sekolah Dasar. Sekolah Dasar: Kajian Teori Dan Praktik Pendidikan, 26(1), 4961. Https://Doi.Org/10.17977/Um009v26i12017p049

Setiawan, A. (2019). Mengembangkan Nilai Karakter dan Kemampuan 4C Anak Melalui Pendidikan Seni Tari Di Masa Revolusi Industri 4.0. Didaktis: Jurnal Pendidikan Dan Ilmu Pengetahuan, 19(2). Https://Doi.Org/10.30651/Didaktis.V19i2.2958

Suryaman, S., \& Karyono, H. (2018). Revitalisasi Pendidikan Karakter Sejak Usia Dini Di Kelas Rendah Sekolah Dasar. Sekolah Dasar: Kajian Teori Dan Praktik Pendidikan, 27(1), 10-18. Https://Doi.Org/10.17977/Um009v27i12018p010

Sustiawati, N. L., Suryatini, N. K., \& Mayun Artati, A. A. A. (2018). Pengembangan Desain Pembelajaran Seni Tari Di Sekolah Dasar Berbasis Localgenius Knowledge Berpendekatan Integrated Learning. Mudra Jurnal Seni Budaya, 33(1), 128. Https://Doi.Org/10.31091/Mudra.V33i1.322

Wuryandani, W., Maftuh, B., . S., \& Budimansyah, D. (2014). Pendidikan Karakter Disiplin Di Sekolah Dasar. Jurnal Cakrawala Pendidikan, 2(2). https://doi.org/10.21831/cp.v2i2.2168 